\title{
Actors of the Ottoman Stage \& Walk-Ons of Dramatic Texts: Representation of Non-Muslim Ottomans in the Western-Style Drama
}

\author{
Nilgün Firidinoğlu ${ }^{1}$
}

*This article is prepared with reference to the master dissertation titled "Modern Türk Tiyatro Edebiyatında Gayrimüslim Osmanlıların Temsili" which I completed in 2009 in the Boğaziçi University Institute of Social Sciences Turkish Language and Literature Department.

'Assist. Prof. Dr., İstanbul University, Department of Theatre Criticsm and Dramaturgy, Istanbul, Turkey

\section{ORCID: N.F. 0000-0003-3995-0903}

Corresponding author/Sorumlu yazar: Nilgün Firidinoğlu,

Istanbul University, Department of Theatre Criticsm and Dramaturgy, Istanbul, Turkey E-posta/E-mail: nfiridin@istanbul.edu.tr

Submitted/Başvuru: 26.05.2020 Revision Requested/Revizyon Talebi/: 04.06.2020

Last Revision Received/Son Revizyon: 04.06.2020

Accepted/Kabul: 23.06 .2020

\section{Citation/Atıf:}

Firidinoğlu, Nilgün. "Actors of the Ottoman Stage \& Walk-Ons of Dramatic Texts: Representation of Non-Muslim Ottomans in the Western-Style Drama" Tiyatro Eleştirmenliği ve Dramaturji

Bölümü Dergisi 30, (2020): 1-16.

https://doi.org/10.26650/jtcd.742928

\section{ABSTRACT}

This study analyzes the reasons why representations of non-Muslim Ottomans are so scarce in the works of playwrights who tried to imbue literature with a "national" character, despite the fact that non-Muslims were pioneers in the adoption of Western-style theater in the Ottoman Empire. This paper discusses the representation of non-Muslim Ottomans within the context of the economic and political changes in the Ottoman Empire, focusing on plays that were not adapted from Western literary works and plays written in Turkish by the Ottoman writers. It is argued that the sense of "us" and "them" originated from a nationalist sentiment which intensified during the 19th century in the Ottoman Empire and economic changes which benefited non-Muslims. These factors are what determined the representation of non-Muslim Ottoman characters. It is maintained that an idea of "us" is dominant in the plays written in this period, as non-Muslim elements which mark either the religious or ethnic identity of characters are not included at all, or are conditionally included.

Keywords: Ottoman Theater History, Western-style Theater, Haralambos Cankiyadis, Görenek, Non-Muslim Ottomans 


\section{Introduction}

The Westernization Movement during the Ottoman Empire, which was propelled by the Tanzimat Edict of 1839, brought about various reforms in education, law, and governance as well as in cultural and artistic spheres. The leaders of the Westernization Movement viewed the transformation of cultural and art as fundamental to the process of Westernization. In addition, the majority of reformist intellectuals served in the Translation Chamber (Tercüme Odası), which was the governmental organ of the Ottoman Empire founded to translate scientific and literary works from European sources. Indeed, the Translation Chamber prioritized artistic and cultural transformation. The activities of the Translation Chamber are a testament to the fact that adopting Western culture was considered to be the most significant step in the process of Westernization. Authors who first interacted with the West and became familiar with Western lifestyles through the works they translated intended to spread Western culture. Through translations of Western literary works and their travels to Europe, Ottoman intellectuals became acquitted with theater-which they judged to be the most efficient art form for spreading their ideas. Prominent intellectuals, such as Namık Kemal, Ebuzziya Tevfik, and Ziya Paşa, contributed to the development of Western-style drama within the Ottoman Empire. The popularization of Western-style drama began in the 19th century and became a fixture of social life and became part of the Young Ottomans. ${ }^{1}$ This trend had a significant influence on Ottoman modernization. Ebuzziya Tevfik' ${ }^{2}$ words expertly highlight the effect of this process:

While writing the history of the Young Ottomans, talking about theater and making relation between an organization aiming constituonalism and theater-that is ultimately a means of entertainment- possibly would be found bizarre by many people. It should not be forgotten: The Young Ottomans think to benefit every kind of means of progression and development that could convey them to their main objective freedom and constituonalism. ${ }^{3}$

This excerpt comes from a work by Ebuzziya Tevfik on the history of the Young Ottomans, and it describes the relationship between Western style theater and The Young Ottomans at first hands.

Authors who were writing play including Namık Kemal and other authors who he inspired, viewed Western drama as the most useful form of literature. In an article titled "Theater" published in the Ibret newspaper, Namık Kemal argues that Ortaoyunu is senseless and uses

1 For more information about The Young Ottomans, their importance in the political history of the Ottoman Empire, political programs, and members, see Şerif Mardin, Yeni Osmanlılar Düşüncesinin Doğuşu (İstanbul: İletişim Yayınları, 1996).

2 Ebuzziya Tevfik wrote a play called Ecel-i Kaza in 1872 and the play was performed at the Gedikpaşa Theater in the same year. For detailed information about the first and only play of Ebuzziya Tevfik see Firat Güllü, Vartovyan Kumpanyası Ve Yeni Osmanlılar: Osmanlıya Has Çokkültürlü Bir Politik Tiyatro Girişimi (İstanbul: Boğaziçi Gösteri Sanatları Topluluğu Yayınları, 2008).

3 Güllü, Vartovyan Kumpanyası Ve Yeni Osmanlılar: Osmanlıya Has Çokkültürlü Bir Politik Tiyatro Girişimi, 83-84. 
barely literate words and indecent phrases. ${ }^{4} \mathrm{He}$ goes on to claim that Ortaoyunu is not a form of theater. In contrast, he glorifies European theater, giving examples from its long history. He explains that Ortaoyunu is a form of entertainment that has a detrimental effect on the morality of spectators. ${ }^{5}$ The lasting influence of Namık Kemal's arguments is visible in Manastırl Mehmet Rifat's writings on art and language. He contributed his writing to Ibret under both his own name and as an alias he called "A Soldier" ("Bir Asker"). Mehmet Rifat's thoughts on theater, which were published in the preface of Görenek, strengthened Namik Kemal's determination :"In recent years, through conversations with our masters and reading their articles and seeing their staged plays, I have learned that theater is the most important part of literature, the most poetic form of entertainment, and the most useful part of the narration." Therefore, intellectuals who supported cultural transformation during the Ottoman Empire wanted to replace traditional theatrical forms, such as Ortaoyunu and Karagöz7 (shadow play), with Western drama.

Who were the actors of this cultural transformation? Non-Muslims accelerated the adoption of Western drama in the Ottoman Empire, as they built the physical and technical infrastructure needed for Western theater. Non-Muslims played a crucial role in the development of Western drama, both in terms of literature and performance. Non-Muslims popularized Western-style theater, which was introduced to the Ottoman Empire via embassies and Palace Theater. In 1844 and 1858, Syrian Christian Mikhail Naum staged the first Turkish play with Armenian actors on an Italian-style stage in the Beyoğlu Hacopulo Bazaar. In 1860, The Aramyan Company, founded by Hovannes Kasparyan, transformed a circus building in Gedikpaşa into a theater, and began to build Gedikpaşa's reputation as an alternative to Beyoğlu, which at the time was the center of theater and entertainment in the Ottoman Empire. Şark Tiyatrosu (The Orient Theater) was founded by Sirapyan Hekimyan and his associates. In addition to being the first, all of these companies, prepared the establishment and development of the Gedikpaşa Theater, the professional face of the Ottoman Theater, through the actors and directors that they trained. Thomas Fasulyeciyan was one of the leading actors and directors

4 Ortaoyunu is a traditional performative form. It was performed in an open space around which the audience sat. "An attempt has been made to the ancient Greek mime via Byzantium or commedia dell'arte, as there was a close relationship between the Ottoman Empire and the Italian States. Some scholars, however, are inclined to believe that Ortaoyunu is a fairly new type of entertainment, originating after 1790 as an offspring of Karagöz." Metin And, Drama At The Crossroads: Turkish Performing Arts Link Past And Present, East And West (Istanbul: Isis Press, 1991), 126. For more detailed information see Metin And, Geleneksel Türk Tiyatrosu: Köylü ve Halk Tiyatrosu Gelenekleri (İstanbul: İnkılap Kitabevi, 1985).

5 Namık Kemal, Osmanlı Modernleşmesinin Meseleleri, Bütün Makaleleri 1, Haz. Nergiz Yılmaz Aydoğdu, İsmail Kara (İstanbul: Dergâh Yayınları, 2005), 499.

6 Manastırlı Mehmed Rıfat, Görenek, Evvelîsi gülünç sonu acıklı tiyatro, (y.y.y.: y.t.y.), 2.

7 Traditional shadow theater, known as Karagöz, was a popular form of entertainment throughout the Ottoman Empire. Karagöz involves two dimensional shadows cast on a white translucent material. The colored figures are made from animal skin, preferably camel. See And, Geleneksel Türk Tiyatrosu: Köylü ve Halk Tiyatrosu Gelenekleri. 
during this period. He also produced plays performed at the Gedikpaşa Theater and the Bursa Theater, which was founded by renowned pro-Westernization intellectual Ahmet Vefik Pasha. Furthermore, Madrios Minakyan, founder of the Ottoman Drama Company, contributed greatly to the development of Ottoman theater through the plays he translated, directed, and acted in. Minakyan contributed to the foundation of Darülbedayi (İstanbul Municipality Theater). Moreover, Dikran Çuhayican, founder of Ottoman Opera Company, was highly praised for the musicals he directed, and was seen as a rival to Hagop Vartovyan (Güllü Agop). ${ }^{8}$

Hagop Vartovyan, the founder of the Ottoman Theater Company/Gedikpaşa Theater, was not only a pioneer of Western-style staging, acting, and directing, but also propelled the development of Turkish drama after being given a monopoly on Turkish performances in 1870. Needless to say, the vitality of the theater industry encouraged authors to produce works of drama. In particular, authors who prioritized thesis play were excited by the prospect of spreading their messages through their texts and impressing the audience with visual aspects of the stage. Metin And says that, "If there is not a continuous and active life of theater in a country, it is not possible to raise a generation of playwrights." "His remarks are noteworthy, as they highlight the importance of Hagop Vartovyan's role in the development of drama during the Ottoman Empire. As the number of Turkish plays was limited and the majority of plays adapted from Western originals were criticized as immoral, Vartovyan encouraged prominent writers of the period to produce dramatic texts. After obtaining a monopoly on Turkish performances, he became interested in promoting Turkish plays and attracting Muslims to the theater. Vartovyan's persistent promotion of playwriting was ridiculed in satire magazines. Previously, the persistence of Güllü Agop had been a target of satire magazines, also. He was caricatured in the following joke: "If someone says good morning to him, he answers as, write it as a three act comedy so we can stage it." 10

Although non-Muslim Ottomans played a critical role in the development of Western-style theater in the Ottoman Empire, they were rarely featured as main characters in the plays of the period. This study will examine the socio-political and economic reasons underlying the limited representation of non-Muslim Ottomans, who were the founders of Western-style theater in the Ottoman Empire. This study will focus on plays that were not adapted from Western literary works and plays written in Turkish by Ottoman writers.

8 For further information about the contribution of non-Muslims to the development of Western-style drama in the Ottoman Empire, see Metin And, Osmanlı Tiyatrosu (Ankara: Dost Kitabevi,1999). Refik Ahmet Sevengil, Türk Tiyatrosu Tarihi 3 (Ankara: M.E.B., 1961). Refik Ahmet Sevengil, Türk Tiyatrosu Tarihi 5 (Ankara: M.E.B., 1968).

9 And, Osmanll Tiyatrosu, 164.

10 Ibid., 164. 
Şerif Mardin refers to pro-Westernization intellectuals as "social mobilizers," 11 and notes that "they were aware that public-oriented criticism would be effective in mobilizing the public on behalf of their social policies and political doctrines." 12 Therefore, it is not surprising that the literature of the period, in general, and plays, in particular, were written to bolster social transformation and engaged in critics of various issues, including superficial Westernization, traditional family structure, and the position of women in social life. Authors of the period, such as Şinasi, Namık Kemal, Ebuzziya Tevfik, and Ahmet Mithat Efendi, produced works of theater as a vehicle for spreading the ideology of Westernization among Muslim Ottomans.

Şair Evlenmesi (A Poet's Marriage) is considered to be the first Western-style Turkish play. The story deals with the problem of arranged marriages, which were very common at the time. In the play Eyvah (Alas), written in 1872, Ahmet Mithat takes up the issue of polygamy, which at the time was accepted as a common custom and sanctioned by religious law. Similarly, Zavallı Çocuk (Poor Boy) by Namık Kemal touches upon the theme of traditional relations between men and women as well as familial expectations. Playwrights of this period also criticized superficial understandings of Westernization, which equated modernization with a simple change in consumption habits. In his play Görenek (Custom), Mehmet Rifat criticized pretentiousness and overindulgence in the western lifestyle. Moreover, Zamane Şıklarl (Choices of the time) by Yusufpaşazade Mehmet Nuri, Işste Alafranga (Here Is the Alla Francia) by M.F., and Açık Baş (The Open Head) by Ahmet Mithat criticize the traditional social structure and seek to correct misconceptions about the nature of modernization.

Non-Muslim Ottomans had already started the modernization process among themselves. As a result of their education and relations with non-Muslim Europeans, they were relatively accepting of cultural transformation. In fact, as Roderic Davison states, they served as "agents of change" in the Ottoman Empire. ${ }^{13}$ Davison argues that compared to Muslims, non-Muslims were able to better adapt to Western-style lifestyles and social customs. He states that those who most readily adopted Western lifestyles - including clothing, eating habits, home decoration, and entertainment - were non-Muslims, mainly Armenians. The reform edict of 1856 (Islahat Ferman1), was devised in order to change the legal status of non-Muslim citizens. As Mardin writes, "The Muslim Ottomans were losing their privileged position as a 'sovereign nation' with Islahat Fermanı that tried to establish a form of Ottoman citizenship irrespective of religion "14

The reactions of bureaucrats to the reform edict were paralleled the sensitive reactions of the Muslim community. In particular, the reaction of The Young Ottomans was significant.

11 Şerif Mardin, Türk Modernleşmesi (İstanbul: İletişim Yayınları, 1991), 60.

12 İbid., 60.

13 For further information, see Roderic F. Davison, "The Millets as Agents of Change in the Nineteenth-Century Ottoman Empire", Christians and Jews in the Ottoman Empire: The Functioning of a Plural Society, Ed. Benjamin Braude and Bernard Lewis (New York: Holmes \& Meier Publishers, 1982), 319.

14 Mardin, Türk Modernleşmesi,16. 
The Young Ottomans believed it was possible to prevent separatist movements threatening the unity of the country by "highlighting the concept of patriotism than the emotions as religion and nationalism." ${ }^{15}$ However, the Young Ottomans" concept of "Ottomanism" was fraught with conflict.

On the one hand, Namik Kemal, a leading figure of the Young Ottomans, supported the "establishment of Ottoman Empire citizenship regardless of religion or race."16 On the other hand, he also claimed that the reform edict disregarded Islam and Islamic culture. Indeed, this served as a point of contradiction. That is, the principle of governing all races and religions according to a single set of religious laws cannot be reconciled with secular citizenship. Basing legal authority on the principles of a single dominant religion delegitimized the principle of equality among the citizens. ${ }^{17}$ The Young Ottomans criticized Ali Pasha and Fuat Pasha, who were the architects of the reform edict of 1856, for not protecting Muslims' rights while improving conditions for the Christian community. Namık Kemal wrote: "Greeks and Armenians were protected against tyranny by patriarchates; they received a regular education while Muslims were unable to progress because of a lack of a protection and education." 18 Another leading figure of the Young Ottomans, Ziya Pasha, also opposed full equality for non-Muslim citizens. Indeed, Bozkurt writes that Ziya Pasha "argued that it was impossible to talk about equality between non-Muslims, who were protected by powerful co-religionist states and their religious leader, and Muslims, who did not have a protector."19

Unlike non-Muslims, who do soldiery and were committed to the homeland, with payment, Muslims were laying down their lives, which was another fact, which was against the equality for the Young Ottomans. In that sense, the references to "Gaza"20 tradition mentioned by Ziya Paşa and Namık Kemal in their articles and the relationship that they had emphasized, collapse occurs with the loss of the Gaza spirit, is important. As the religion being fought for was Islam and the soldiers were Muslim, the reference to the owners of the homeland was obvious. Thus, in the play Vatan Yahut Silistre (The Fatherland) Namik Kemal wanted to invigorate the Gaza spirit, which was animated by the Islamic religion and could motivate soldiers to fight for the homeland.

The Young Ottomans were referring to the Islamic tradition of the state, because of "the innate attitude of superiority which the Muslim Turks possessed." ${ }^{21}$ Cooperation with non-

15 Gülnihal Bozkurt, Gayrimüslim Osmanlı Vatandaşlarının Hukuki Durumu (1839-1914) (Ankara: TTK, 1989), 109.

16 Mardin, Yeni Osmanlı Düşüncesinin Doğuşu, 367.

17 Ibid., pp.366-367.

18 Bozkurt, Gayrimüslim Osmanlı Vatandaşlarının Hukuki Durumu (1839-1914), 109.

19 Ibid., 109.

20 For subtle analysis of Gaza see Cemal Kafadar, Between Two Worlds: The construction of the Ottoman state, (Berkeley: University of California Press, 1995).

21 Roderic H. Davison, Osmanlı Türk Tarihi (1774-1923) (İstanbul: Alkım Yayınevi, 2004), 166. 
Muslims for the sake of national unity alongside the separation of privileges was based on a sense of inner superiority. Indeed, "the concept of the Ottoman always contained both the idea of commitment to the Ottoman state and a strong Muslim traditionalism." 22 Despite all of the egalitarian promises made to non-Muslims and the work of the right of representation that is regulated by the constitution of Young Ottomans, an exclusionist attitude still prevailed in many discussions.

Namık Kemal wrote, "Christians' need for reformation is not as vital as the Muslims' need for reformation. They do not die for their country although they enjoy all the utilities of it." ${ }^{23}$ Not surprisingly, he defines Ottoman identity as being specifically Muslim in his renowned play, Vatan yahut Silistre. Namık Kemal's Vatan Yahut Silistre is a prominent work in the history of theater and the politics of the Ottoman Empire, as it managed to mobilize the population. In the work, "country" is depicted as land for which Muslims are ready to die. Therefore, non-Muslim Ottomans are excluded from the cast of "social mobilizers" carrying out the social transformation of society. Tanzimat intellectuals and playwrights produced plays which were made primarily for Muslim audiences and featured primarily Muslim characters.

It is reasonable to assert that intellectuals in Tanzimat who aimed to establish a National Ottoman Theater had been influenced by the development of European theater and its "national" character, which they had witnessed in Europe. In the same period, each European country had developed their own original texts and well-established theater companies. Indeed, each country had its own traditional of national theaters which benefited from well-organized institutions and were nurtured by theoretical debates. The easing of censorship in 1791 after the debates generated by the French academy and new trials in French theater was orienting the European theater. By the late 18th century, the contributions of Goethe and Schiller allowed German national theater to rival the greatness of English and French theater. However, in the $19^{\text {th }}$ century in the Ottoman Empire, theater was still in its initial stages. Discussions about how to write, act, and stage a play dominated debates at the time. The majority of actors were Armenian and their "broken Turkish" was difficult to understand. Apart from the lack of literary and aesthetical integrity, there was a lack of language unity. The problem of language unity was the subject of countless intense debates, and it took many years to resolve this problem.

Humor magazines ridiculed miscommunications between actors and the audience that resulted from the broken Turkish being spoken on the stage. The publication Diyojen, run by Teodor Kasap, featured many such criticisms. Translated plays were often criticized for being at odds with Ottoman moral values. In an anonymous article published in Diyojen, one person wrote, "The company of Güllü Agop can be labeled as an Armenian, French, Italian, or an English company but certainly not as an Ottoman company, as it does not include any

22 Ibid., 187.

23 Bozkurt, Gayrimüslim Osmanlı Vatandaşlarının Hukuki Durumu (1839-1914), 285. 
elements peculiar to the Ottoman." ${ }^{24}$ In 1873, a Theater Committee was established to confront the problems facing Ottoman theater. Committee members gave lessons in articulation and translated Western plays into Turkish. The activities of the committee were dictated by both artistic concerns and the criticisms published in newspapers about Gedikpaşa Theater Company and its director Hagop Vartovyan (Güllü Agop). Karnik Stephanyan’s remarks about the activities of the committee reflect these concerns:

The apparent function of the Committee was to check the use of language in Turkish performances. However, the existence of members who did not have anything to do with literature or art sufficiently reflects the real purpose of the Committee. Members included Ali Bey, Governor of Trabzon, Nazım Bey, Ebuzziya Tevfik, Hoca Hakkı, Bedri Bey, Abdullah Hamit, Mahmut Nedim, Namık Kemal, Ahmet Mithat Efendi, and Şemsettin Sami. According to the Committee's manifesto, which was shaped by the Young Ottomans, the political ideology of Vartovyan was to be followed and the real "National Ottoman Theater" was to be formed by using technical facilities and supplies of this theater. There were two ways to realize this goal. The first was to cultivate creative powers in theater and the second was to support playwriting. ${ }^{25}$

As Stephanyan indicates, producing national texts was considered to be the most effortless method for creating a national Ottoman theater. The plays staged were criticized for lacking national spirit. Therefore, it was not particularly difficult to encourage young playwrights to attempt to produce "national" texts. Adaptations of Western literary works were criticized for conflicting with national moral values; as such, playwrights channeled their energies into creating national works. Important playwrights of the period who were influenced by Ottomanism attempted to produce original "national" texts by portraying the "dominant nation" through its language and ethics. As a result, they produced plays with protagonists that were mainly Muslim Ottomans.

A survey of the plays written by prominent playwrights of the 19th century reveals multiple examples of this tendency. For instance, in Akif Bey (1874) by Namik Kemal, 26 the only non-Muslim Ottoman character is a barkeep named Nikoli. The character of a Greek barkeep appears in Karagöz (Shadow Play) as well. ${ }^{27}$ The character of a non-Muslim barkeep emerged as a common stereotype during the Ottoman Empire, as Muslims are forbidden from producing and trading alcoholic beverages. If we consider the Namik Kemal's harsh feelings toward traditional theater, we can claim that Nikoli was not transferred from Karagöz. Both in Karagöz (as a traditional performative form) and Akif Bey (as a western form), the image of the nonMuslim barkeep is derived from the same social structure. In Karagöz, puppets speak with an accent determined by their position within society. Together with misunderstandings, making

24 Diyojen 161, (9 Teşrinisani 1288/ 21 November 1872), 2.

25 Güllü, Vartovyan Kumpanyası ve Yeni Osmanlılar, 49-50.

26 Namık Kemal, Akif Bey, Tertip Eden: Mustafa Nihat Özön (İstanbul: Remzi Kitabevi, 1972).

27 Cevdet Kudret, Karagöz Cilt I (İstanbul: Yapı Kredi Yayınları, 2004), 24. 
puppets speak in such a way is comedic and reveals the artifice of hayali (puppet master/ puppeteer) usage of the language. However, transcending all of these issues, the persistence of the character of the non-Muslim barkeep is best explained by the fact that an agreement on nationalistic ideals and a unity of language among Karagöz performers and spectators had not yet occurred by the beginning of the 20th century. In Akif Bey, there is no difference between the Turkish language performance of Akif Bey and Nikoli the barkeep. Undoubtedly, this is an example of the ideal of "National Ottoman Theater," that is, to create works written and performed in Turkish without an accent. On the page of character descriptions, the barkeep character is referred to as "Nikoli the barkeep." However, in the scenes that he appears in, he is mentioned only as the barkeep, and the other characters also refer to him this way.

A similar representation appears in $A c ̧ ı k B a s ̧$ (1875) by Ahmet Mithat. 28 The character of Elena Dudu, a peddler woman who appears in only one scene of the play, is likely Greek. Elena Dudu's role is to act as a go between for Hesna Hanım and Numan Bey, who are engaged in a secret affair. Very similar to Nikoli the barkeep in Akif Bey, Elena Dudu also speaks without an accent. The play Iskat-ı Cenin (1876) by Hasan Bedrettin Paşa tells the story of two young lovers who are prevented from being together. When they finally do reunite, the story ends in a disaster.29 Moreover, the play criticizes people who indulge in luxuries and subsequently find themselves in a financial and emotional collapse.

In Iskat-l Cenin, there are non-Muslim characters who play a supportive role function to bring resolve to the narrative; however, their names do not appear on the character list. They are simply listed as "doktor" (doctor) and "sarraf" (moneychanger) at the end of the character list. The name of the doctor in the play is Yanni. However, in the play, this Greek name is mentioned only once. Muslim characters simply refer to him as "doctor." The name of the other moneychanger in the play is Alfons. The moneychanger cooperates with him to get his money back from the evil character Şevki. The play does not contain any information about the ethnic identity of the moneychanger character. However, because moneychanger shop is in Galata, which was primarily occupied by non-Muslims, we can assume that he is not Muslim. Another non-Muslim character is Doctor Yanni, who conspires with Şevki and Kethüda Kadın to cause the death of a pregnant woman for money. In contrast with the plays mentioned above, doctor Yanni speaks Ottoman Turkish with a Greek accent.

There are a very limited number of plays written in the Tanzimat period that have a non-Muslim main character. Indeed, the lives and actions of non-Muslim characters are

28 Ahmet Mithat Efendi'nin Tiyatrolarl, Haz. İnci Enginün (İstanbul, Marmara Üniversitesi Yayınları, 1990).

29 Hasan Bedrettin Paşa, Iskat-l Cenin, Facia, dört fasıl, dört perde (İstanbul: 1292/1876). The idea of the Iskat-l Cenin has come out from the articles on abortion written by Namik Kemal published with the title of "Population" in Ibret and "Iskat-i Cenin" in Hadika. For these articles see Kemal, Osmanl Modernleşmesinin Meseleleri, Bütün Makaleleri 1, 69-466-542. See also Namık Kemal, Namık Kemal'in Mektupları I, Haz. Fevziye Abdullah Tansel (Ankara: Türk Tarih Kurumu, 1967), 314-315. 
instrumentalized to criticize the loss of moral values and anti-social attitudes, which pose a potential threat to the social order and ethical norms. Indeed, non-Muslim characters are depicted as agents of moral decline. Studies on the literature of this period reveal that antisocial thinking and values which clashed with dominant norms were criticized through the use of female non-Muslim characters. ${ }^{30}$ As a result, plays written in the same period depict female non-Muslims as immoral people.

In an article on the plays of Osman Hamdi Bey, Metin And writes, "All these three plays are comedies and they emulate French comedies. As a result, because the man-woman relationship does not conform to the moral values of the Muslim community, the theme goes around the Christian minority in all three plays." ${ }^{31}$ The writers of the period were unaware of the moral values and sensibilities of the communities they lived with. Teodor Kasap's remarks testify to this ignorance: "Turks could not appreciate Zor Nikah (Tough Marriage) even if they are forced to. It is likely that even Christians would not tolerate Kokana Yatıyor (Elderly Greek Woman Sleeping)." ${ }^{32}$ Hence, Metin And's transferring authors preference without criticizing so normalizing it worth being the subject of another article on our theater historiography.

Osman Hamdi Bey's İki Karpuz Bir Koltuğa Sığmaz (Do Not Have Too Many Irons in Your Fire, 1872) is a three act comedy play of intrigue which deals with a secret correspondence between two married Armenian women and an Armenian man. A similar play is Iddianin Sonu Cinayet (The End of the Bet is Murder) by Mahmut Şevket Bin Bekir Naci. In this play, the two protagonists, Madam Marika and Mösyö Nikolaki, see a signboard which says "the deceit of men defeated women" and make a bet. Marika thinks that she can deceive her husband by flirting with another man and win the bet. The play ends with the death of Marika and Nikolaki as a result of their trickery.

\section{Concerns about Economic Superiority}

Beginning in the middle of the 19th century, the idea of Ottomanism began to be reformulated as an identity dominated by Muslim and Turkish beliefs and sensibilities. However, Ahmet Mithat has pointed out that this situation is not the result of unfair competition, but rather a natural result of Ottomans' tendencies:

30 I say "usually" because we encounter the plays in which Muslim Ottoman women are represented in a similar way. Dilruba in the Akif Bey and Hesna in the Açık Baş can be mentioned as the first examples that come to mind. It does not matter whether Muslim or non-Muslim, women are represented according to the rules of a patriarchal system.

31 Metin And, “Osman Hamdi Bey’in Komedyalar1”, Popüler Tarih Şubat 2001, 94-95.

32 Diyojen 168 (25 Teşrinisani 1288/ 7 December 1872), 1-3. Kokona Yatıyor was adapted from Eugene Grange\&Victor Bernard's play Madame est couchee by Ali Bey. 
Private enterprise and trade in our Istanbul have not yet been awakened. No one from the upper classes are eager to make a profit. Those who have inherited lands from their ancestors use them as a place for recreation. Everyone has their eyes on civil service. They don't know any other form of living. How will the state treasury feed those who have their eyes only on civil service for their livelihood? Not with income? Will it not secure an income through agriculture, industry, trade, or as a shepherd? Income will be poor as long as they are in the hand of lazy people. ${ }^{33}$

In works of literature, Muslim Ottomans were primarily represented as lazy civil servants who do not do their jobs and as idlers or benefiting from the wealth of their fathers. In contrast, non-Muslims are represented as moneychangers, doctors, bankers, and peddlers. This is a reflection of Ahmet Mithat's determination. Such occupations were not closed to Muslims. Moreover, in his novel Felatun Bey ve Rakım Efendi, Ahmet Mithat describes a positive outcome for Rakım Efendi's business venture in addition to his current job. Representation of these characters that writers critically approached in the literature after the Tanzimat is the appearance of a civil servant mentality that has interiorized. Therefore, the anger against rich non-Muslims displayed in these narratives is not a reflection of barriers put in place for hard-working Muslim Ottomans, nor is a reflection of their businesses being hindered. Either consciously or unconsciously, this anger was provoked by the concern of the valid cyclical power, the capital, could change the condemned nation into a dominant position.

The examples discussed in this section of the paper reflect the concerns of a dominant nation in relation to the economic superiority of non-Muslims. The plays Görenek (1874) by Manastırlı Mehmet Rifat and Haralambos Cankiyadis (1912) by Safveti Ziya illustrate this expertly. Indeed, in these plays non-Muslims are represented as usurers, self-seekers, and exploiters within society.

\section{Görenek}

In the Ottoman Empire, changes in economic power balances resulted in increased consumption, higher demand for European products, and the pursuit of a garish lifestyle. Writers witnessed this during their time and mentioned this consumption habit and criticized lavishness. Writers tended to highlight those with self-seeking attitudes in the Ottoman Empire who were indebted to lenders. Manastırlı Mehmet Rıfat's Görenek (1874) is a significant text, as it describes the public's distrust of non-Muslim merchants with both economic and political references. 34 In Görenek, a non-Muslim peddler woman lends cash to a Muslim women. Her mission is not to support the entanglements that are typical in literary texts. The three

33 Orhan Okay, Batı Medeniyeti Karşısında Ahmet Mihat Efendi (İstanbul: MEB Yayınları,1991), 111.

34 Görenek was written with inspiration from the article "Custom" written by Namık Kemal. Namık Kemal wrote a letter from exile in Magosa to Mehmet Rifat after he had read Görenek, Ya Şehid Ya Gazi, and Iskat-l Cenin. He started this letter by saying "Long live the Young Ottomans." Throughout the letter, he praised the authors of these plays. See Tansel, Namık Kemal'in Hususi Mektupları 1, 316-319. 
act play Görenek discusses tensions within the family and society that result from conflicts between traditional customs and the realities of everyday life. The circumcision ceremony, organized by Numan and Cevriye Hanım for their sons, causes economic suffering due to the flatulency of both the hosts and the guests. For this reason, informed and uninformed loans and jewelry are sold, causing material and nonmaterial problems. In this sense, as the author states, Görenek is the "first funny and tragic work of theater."

The only non-Muslim character in Görenek is Mannik Dudu. ${ }^{35}$ Mannik Dudu is represented as a cunning, shifty peddler. She takes advantage of Turkish women's frailty. Mannik Dudu first appears in the second act of the play. At first glance, her appearance can be explained according to the patriarchal gender norms of the time which did not allow for a Muslim woman to meet with a man to sell her diamonds or to walk around jewelry shops. Before the character of Mannik Dudu appears in the play, she is referred to as both "a peddler woman" and "Mannik Dudu" in the conversations of other characters. As a non-Muslim merchant, Mannik is a tool that is used to rescue Nesibe Hanım, the guest of the wedding. During the negotiations between Nesibe and Mannik, they continually refer to a non-Muslim peddler woman is as "Dudu."

Subsequently, the writer abandons his critical representation of Mannik Dudu as a woman who criticizes the consumption habits of Turkish women. However, he does not feature the clever and positive female character of Dudu. So-called "Dear Dudu" of Nesibe, who is impatient to sell her diamonds, becomes "a misbeliever women" (kafir kadın) who is late delivering payment for the diamonds:

Nesibe: The misbeliever woman has not come yet. She is playing hard to get.

Chamberlain: That's how they are, my dear. They prey on a person's bad moment... ${ }^{36}$

By the end of the play, a series of expected conclusions materialize: a man becomes paralyzed and a family is separated. However, the only person who is not affected by these events - and actually comes out ahead - is the Armenian peddler Mannik Dudu. In the play, Muslim Ottoman women are stigmatized as "spendthrift," "spoiled," and "show-offs" and they lose money. In contrast, non-Muslim women are depicted as "opportunistic", "knowit-alls" and makes profit.This contrast plays out on a political and economic plane, and the texts reflect a polarized perception of "us" and "them." As a matter of fact, we saw that this contrast created, in a social life environment, reached serious dimensions in the play called Haralambos Cankiyadis by Safveti Ziya. This play was written in 1912, and the events it depicts took place before the Second Constitutional Period, during the years when Ottoman identity was being constructed from both Turkishness" and "Islamism."

35 According to the TDK (The Turkish Language Association) the term Dudu has three definitions. Two of three definitions are related to the story here: 1. Dudu: a title given to woman, Hanım 2. Old Armenian woman. Online: https://sozluk.gov.tr

36 Manastırlı Mehmet Rıfat, Görenek Evvelîsi gülünç sonu acıklı tiyatro, 60. 


\section{Shylock of the Ottoman: Haralambos Cankiyadis}

The Ottoman Empire was unable to pay the salaries of its officers due to the increasing economic crisis of the 19th century. This situation provided new opportunities for people who had the financial resources to take part in money changing and jewelry. These people were mostly non-Muslim Ottomans. Bankers from Galata, ${ }^{37}$ of which there were approximately 42 at the end of the 19th century, began providing loans with high rates of interest to officers and also the pashas who negotiated their paychecks.

Haralambos Cankiyadis (1912) is the only play written by Safveti Ziya, a Servet-i Fünun writer. 38 The story focuses on a Greek moneychanger named Haralambos Efendi from Kayseri. He was a non-Muslim banker who shaped the economic life of the Ottomans in the19th century. The events of Haralambos Cankiyadis occur in Beyoğlu before the Second Constitutional Period (1908). The protagonist is very successful at his job, and conforms to professional etiquette while dealing with clients and the crisis created by the lenders of both officers and pashas in his life. The play mentions both the moneychanger, who relies on central weakness and uncontrolled mechanisms of the state, and the political and economic upheavals of the era of Abdülhamid II. However, Safveti Ziya places Haralambos Cankiyadis, a profiteering and opportunistic character, at the center of the narrative.

The list of characters on the fourth page of the play pitted the "profiteering rich" against the poor. All of the characters besides Dikran, Haralambos, Dimitraki, the servant Temistokli, and Haralambos's son Filip are civil servants. Vartan, Sarkis, Dimitraki, and Pandalaki, who are talked about in the play, work as moneychangers and as jewelers (Vartan) in the Grand Bazaar.

In Namık Kemal's words: "What did we gain by being officers, while we were experiencing difficulty, the Christians did dealings in arts and commerce and reached the level of Europe." ${ }^{39}$ In this context, discussing arts and commerce as an alternative to being an officer implies that the resources held by Christians must be taken back. He discusses non-Muslims who have become rich and now equal that of Europeans as if they were the citizens of another state. Indeed, he does not consider their achievements to be the achievements of Ottomans. Inevitably, this approach criticizes the success and wealth of Christian figures in the Empire and excludes them from Ottoman identity. Wealthy non-Muslims are seen as stealing resources and opportunities from the real owners of the country. That is, they are seen as not a part of "us."

This play has a special place in the history of Ottoman drama, as it features a non-Muslim character. Haralambos Cankiyadis, a Greek Ottoman broker in Galata, is depicted as a Shylock

37 Haydar Kazgan, Galata Bankerleri (İstanbul: Tük Ekonomi Bankası,1991), 3.

38 Safvetî Ziya, Haralambos Cankiyadis (İstanbul: Matbaa-i Ahmet ihsan ve Şürekâsı, Muhtar Halit Kütüphanesi Külliyat1, 1912).

39 Bozkurt, Gayrimüslim Osmanlı Vatandaşlarının Hukuki Durumu (1839-1914), 157. 
who exploits members of the Ottoman officialdom. The play neatly parallels the Shylock character in Shakespeare's The Merchant of Venice and the character Haralambos. The negative depiction of money changing as usury following the economic collapse and Western capitalism is blamed on the Greek moneychanger. Muslim characters describe Haralambos using adjectives such as "blood dryer," "heartbreaker," "merciless," "unjust," "ignoble," "swindler," and "robber." Moreover, the writer refers to Shakespeare's play The Merchant of Venice. Indeed, he intentionally draws a comparison between Haralambos and the usurer Shylock, who insisted on applying the legal contract which states that "a pound of flesh will be cut from Antonio instead of unpaid debt." Safveti Ziya argues that Haralambos is an even more merciless character than the Shylock. Similar rich literary references are not employed in the description of the Muslim ottoman civil servants or the soldiers who do nothing but hang out with "French cocotte" and wait at the front doors of the money changers to broker their paychecks. Despite criticizing their degeneracy and addiction to nightlife, he depicts them as victims and legitimizes their behavior.

From this perspective, it would be wrong to say they are captured to be civil servants and obliged to suffer from boredom as Namık Kemal emphasized. Own attitudes of Muslim Ottomans prepared background to move away from arts or trade. Muslim Ottomans do not even consider ideal alternative solutions in Haralambos Cankiyadis. For instance, the character Şefik chooses to be a lowly enlisted civil servant, despite struggling to provide enough money for his mistress. ${ }^{40}$ In the play he "fall into the usurer's hands", the Ottomans are mostly soldiers, and bureaucrats. People of varying social status become indebted to Haralambos. This situation reflects the situation within the Empire at the time, where domestic borrowing was increasing. Concerning this point, Sina Akşin's thoughts reveal the reason for the emotional intensity of the borrower to Ottoman's reproach:

Beginning from the middle of the 19th century, it can be said that there was capitalist development in the Ottoman Empire, but this development was composed of the investment of Western capitalism or minorities. This view, for a Turk who has no idea about Bourgeois ideology, is quite strange and could produce emotional reactions such as admiration, amazement, disinterestedness, and hostility. ${ }^{41}$

What is crucial in Akşin's statement here is the reaction "at the level of emotion." This emotion, just like in Görenek, being expressed as "anger" again in Haralambos Cankiyadis. Other non-Muslim characters are also affected "at the level of emotion," which Sina Akşin underlines as follows:

40 Ziya, Haralambos Cankiyadis, 102.

41 Sina Akşin, Jön Türkler ve İttihat ve Terakki (Ankara: İmge Kitabevi, 2006), 123. 


\begin{abstract}
Selim Pasha:
Ok ok, you are the apple of my eye, whenever you call me I will come...don't worry.... I will give you my personal card, so that you can then take your pendant from Vartan.

Firida: (pouts his lips) Vartan does not accept cards, if you want to buy it, you need to pay for it!!!

Selim Pasha:

Ahhh!!! Isn't he an Armenian? He always bears a grudge against me... But I will pay him back for it. ${ }^{42}$
\end{abstract}

In the play, the naturalness of demanding money only for the goods sold by Armenian jeweler Vartan becomes an incomprehensible demand for Selim Pasha and those like him. For Selim Pasha who are used to doing their jobs while exploiting their positions and influence, there is no difference between a card and money. At this point in the play, Safveti Ziya legitimizes the Selim Pasha's anger instead of Vartan's natural demand. Vartan assumes a poor attitude as an Armenian and does not accept the card. The borrowed community, who are unable to evaluate their own economic situation and are afraid of opposing the state or emperor despite their awareness, express their anger at non-Muslim moneychangers, bankers, and merchants. Accordingly, they hide their unproductivity and develop an irrational relationship between being Muslim and being confiscated. This relationship reproduce the conflict between nonMuslims and Muslims. More examples of this conflict can be found in Haralambos Cankiyadis.

In conclusion, the art of theater during the Ottoman Empire flourished thanks to the contributions of non-Muslims, particularly Armenians, in acting, directing, and management. Playwriting became popular among writers, as it was a source of both income and fame. However, non-Muslims were ignored in texts which were intended to have a "national" character in terms of characters, message, setting, and plot. Indeed, these plays were produced by playwrights who were motivated to create a national drama. In the plays which do contain non-Muslim characters, these characters are mostly represented as poorly behaved members of society. These plays are significant in that they reflect the concerns of dominant members of society in the context of the economic superiority of non-Muslims around the end of the 19 th century. Indeed, on the level of narrative, these writers reflect the "concerned attitude" of a dominant nation which was reacting to the economic power of non-Muslims.

Peer-review: Externally peer-reviewed.

Conflict of Interest: The author has no conflict of interest to declare.

Grant Support: The author declared that this study has received no financial support.

Hakem Değerlendirmesi: Dış bağımsız.

Çıkar Çatışması: Yazar çıkar çatışması bildirmemiştir.

Finansal Destek: Yazar bu çalışma için finansal destek almadığını beyan etmiştir.

42 Ziya, Haralambos Cankiyadis, 60. 


\section{BIBLIOGRAPHY}

Ahmet Mithat Efendinin Tiyatroları, Hazırlayan İnci Enginün, İstanbul: Marmara Üniversitesi Yayınları, 1990.

Akşin, Sina. Jön Tü̈kler ve Ittihat ve Terakki, Ankara: Imge Kitabevi, 2006.

Ali Bey, Kokona Yatıyor, İstanbul: Mitos Boyut Yayınları, 2001.

And, Metin. "Osman Hamdi Bey’in Komedyaları", Popüler Tarih Şubat 2001.

And, Metin. Osmanlı Tiyatrosu, Ankara: Dost Kitabevi, 1999.

Bozkurt, Gülnihal. Gayrimüslim Osmanlı Vatandaşlarının Hukuki Durumu (1839-1914), Ankara: TTK, 1989.

Davison, Roderic F. “The Millets as Agents of Change in the Nineteenth-Century Ottoman Empire”, Christians and Jews in the Ottoman Empire: The Functioning of a Plural Society. Editör Benjamin Braude and Bernard Lewis, New York: Holmes \& Meier Publishers, 1982.

Davison, Roderic F. Osmanlı Türk Tarihi (1774-1923), Istanbul: Alkım Yayınevi, 2004.

Diyojen 161, 9 Teşrinisani 1288/ 21 November 1872.

Diyojen 168, 25 Teşrinisani 1288/ 7 December 1872.

Güllü, Fırat. Vartovyan Kumpanyası Ve Yeni Osmanlılar: Osmanlıya Has Çokkültürlü Bir Politik Tiyatro Girişimi, İstanbul: Boğaziçi Gösteri Sanatları Topluluğu Yayınları, 2008.

Hasan Bedrettin Paşa, Iskat-ı Cenin, Facia, dört fasıl, dört perde, İstanbul: 1292/1876.

Kazgan, Haydar. Galata Bankerleri, Istanbul: Türk Ekonomi Bankası, 1991.

Kemal, Namık. Akif Bey, Tertip Eden: Mustafa Nihat Özön, İstanbul: Remzi Kitabevi, 1972.

Kemal, Namık. Osmanlı Modernleşmesinin Meseleleri, Bütün Makaleleri 1, Hazırlayan Nergiz Yılmaz Aydoğdu and İsmail Kara, İstanbul: Dergâh Yayınları, 2005.

Kudret, Cevdet. Karagöz Cilt I, İstanbul: Yapı Kredi Yayınları, 2004.

Manastırlı Mehmet Rıfat, Görenek Evvelìsi guilü̈ç sonu acıklı tiyatro, y.y.y: y.t.y..

Mardin, Şerif. Türk Modernleșmesi, Istanbul: Iletiş̧im Yayınları, 1991.

Mardin, Şerif. Yeni Osmanlı Dǚ̈ü̈ncesinin Dogǔşu, Istanbul: Iletişsim Yayınları, 2008.

Okay, Orhan. Batı Medeniyeti Karşısında Ahmet Mihat Efendi, Istanbul: MEB Yayınları, 1991.

Sevengil, Refik Ahmet. Türk Tiyatrosu Tarihi 3, Ankara: M.E.B., 1961.

Sevengil, Refik Ahmet. Türk Tiyatrosu Tarihi 5, Ankara: M.E.B., 1968.

Tansel, FevziyeAbdullah. Namık Kemal in Hususi Mektupları 1, Ankara: Türk Tarih Kurumu Basımevi, 1967.

Ziya, Safvetî. Haralambos Cankiyadis, Istanbul: Matbaa-i Ahmet İhsan ve Sürekâsı, Muhtar Halit

Kütüphanesi Kuilliyat1, 1912. 